KATARZYNA MAJCHRZAK

Wydział Prawa Kanonicznego

Uniwersytetu Kardynała Stefana Wyszyńskiego w Warszawie

\title{
UPROWADZENIE BĄDŹ ZATRZYMANIE MAŁOLETNIEGO LUB OSOBY NIEPORADNEJ W ŚWIETLE ART. 211 KODEKSU KARNEGO
}

Treść: Wstęp. - 1. Przedmiot ochrony. - 2. Podmiot czynu zabronionego. - 3. Znamiona strony przedmiotowej. -4 . Znamiona strony podmiotowej. - 5. Sankcja karna. - Zakończenie.

\section{Wstęp}

Niniejszy artykuł ma na celu przedstawienie normatywnej regulacji przestępstwa określonego w art. 211 k.k. ${ }^{1}$ Zgodnie z tym przepisem, kto wbrew woli osoby powołanej do opieki lub nadzoru, uprowadza lub zatrzymuje małoletniego poniżej lat 15 albo osobę nieporadną ze względu na jej stan psychiczny lub fizyczny, podlega karze pozbawienia wolności od 3 miesięcy do lat 5. Ustawodawca umieścił to przestępstwo w katalogu przestępstw skierowanych przeciwko rodzinie i opiece. Głównym celem jest zapewnienie prawidłowego funkcjonowania rodziny, zwłaszcza w kontekście funkcji opiekuńczo-wychowawczej. Przy czym omawiane przestępstwo może dotyczyć rodziny w szerszym tego słowa znaczeniu, niż tylko na styku rodzice - dzieci. Osoba powołana do opieki lub nadzoru to nie tylko rodzice, chociaż najczęściej to oni sprawują pieczę nad dzieckiem, jeśli przysługuje im władza rodzicielska.

\footnotetext{
${ }^{1}$ Ustawa z dnia 6 czerwca 1997 r. Kodeks karny (Dz. U. z 2016 r. poz. 1137, z późn. $\mathrm{zm}$.).
} 


\section{Podmiot ochrony}

Dobrem chronionym na gruncie omawianego przepisu art. 211 k.k. jest instytucja opieki i nadzoru nad małoletnim lub osobą nieporadną. Chodzi tutaj o ochronę prawidłowego i niezakłóconego wykonywania prawa do opieki nad konkretną osobą. Jest to stanowisko większości doktryny ${ }^{2}$. Jednym z argumentów przemawiających za słusznością tej tezy jest umieszczenie tego przestępstwa w rozdziale XXVI kodeksu karnego odnoszącym się do przestępstw przeciwko rodzinie i opiece. Innym ważnym argumentem jest wskazanie, że opieka i nadzór ustanawiane są w trosce o dobro małoletniego lub osoby nieporadnej, dlatego też działania godzące w funkcjonowanie opieki lub nadzoru naruszają jednocześnie dobro osoby poddanej opiece lub nadzorowi. Ustawodawca nie miał na myśli opieki czy nadzoru, jako instytucji ujętej w sposób abstrakcyjny, ale z pewnością celem wprowadzenia tej regulacji była ochrona dóbr, którym ta instytucja służy czyli osób pozostających pod opieką lub nadzorem, a pośrednio także osób sprawujących tę opiekę ${ }^{3}$. Również Sąd Najwyższy zajął, w tej kwestii jasne stanowisko wskazując, że przedmiotem ochrony karnoprawnej z art. 211 k.k.: „Nie jest wolność osoby uprowadzonej czy zatrzymanej, jak również nie jest przedmiotem tej ochrony treść orzeczeń sądowych dotyczących sprawowania opieki lub nadzoru nad tą osobą, lecz instytucja samej opieki i nadzoru"4.

\section{Podmiot czynu zabronionego}

Prawo do sprawowania opieki i nadzoru powinno opierać się na konkretnym tytule prawnym. Podstawą powołania do opieki może być ustawa, orzeczenie sądu czy umowa. Jednakże szczególne okoliczności faktyczne także mogą być podstawą do sprawowania opieki lub

\footnotetext{
${ }^{2}$ M. Mozgawa, Przestępstwa przeciwko rodzinie i opiece, w: Kodeks Karny. Komentarz, red. M. Mozgawa, Warszawa 2013, s. 497; Z. SiwıK, Przestępstwa przeciwko rodzinie i opiece, w: Kodeks Karny. Komentarz, red. M. Filar, Warszawa 2012, s. 1059.

${ }^{3}$ R. A. Stefański, Przestępstwo uprowadzenia małoletniego (art. 211 k.k.), Prokuratura i Prawo nr 9/1999, s. 59.

${ }^{4}$ Postanowienie Sądu Najwyższego z dnia 18 grudnia 1992, sygn. akt I KZP 40/92, Wokanda nr 2/1993, poz. 8.
} 
nadzoru. Przykładem faktycznego powierzenia opieki nad dzieckiem, nie wynikającym z żadnego prawnego uregulowania, będzie pozostawienie czasowo dziecka pod opieką babci, przyjaciółki czy sąsiada. W takim przypadku zatrzymanie dziecka wbrew woli oddającego czy jego uprowadzenie będzie również stanowiło przestępstwo z art. 211 k.k. Należy zgodzić się z poglądem, iż poszerzenie kręgu osób powołanych do opieki lub nadzoru (w świetle omawianego przepisu) o osoby, którym powierzono ją w sposób faktyczny jest bardziej korzystne dla ochrony dziecka czy osoby nieporadnej ${ }^{5}$. Z kolei powołanie do nadzoru może wynikać ze szczególnych kompetencji osób uprawnionych, np. zarządzających domami dziecka czy lekarzy i personelu pomocniczego w zamkniętym zakładzie leczniczym ${ }^{6}$. Ustawodawca w art. 211 wyraźnie wskazał na osobę powołaną do opieki lub nadzoru. Należy zatem odróżnić osobę powołaną od osoby sprawującej opiekę lub nadzór. Osobą powołaną do sprawowania opieki nad małoletnim najczęściej jest rodzic z pełną władzą rodzicielską. Jednak sprawującym opiekę może być także przysposabiający, opiekun, kurator czy inna osoba sprawująca tzw. pieczę zastępczą. Zaś osobą powołaną do opieki będzie nie tylko osoba, która legalnie sprawuje opiekę, ale również osoba, która jest powołana (uprawniona) do opieki chociaż faktycznie tej opieki z różnych powodów nie wykonuje.

Sprawcą przestępstwa $\mathrm{z}$ art. 211 k.k. może być każda osoba działająca „wbrew woli osoby powołanej do opieki lub nadzoru”. Jest to przestępstwo powszechne. Dlatego nie sposób zgodzić się z odmiennym poglądem, iż sprawca musi mieć szczególny motyw działania, a w konsekwencji, że mogłoby to być przestępstwo quasi-indywidualne. Zdaniem większości doktryny i orzecznictwa sprawcą tego przestępstwa nie mogą być rodzice, którym przysługuje pełna władza rodzicielska, chyba że zostali pozbawieni władzy lub nastąpi jej zawieszenie czy ograniczenie na podstawie przepisów kodeksu rodzinnego i opiekuńczego. Przy czym nawet jeżeli rodzice nie mieszkają razem,

${ }^{5}$ S. Hypś, Przestępstwa przeciwko rodzinie i opiece, w: Kodeks karny. Część szczególna. Tom I. Komentarz, red. M. Królikowski - R. Zawłocki, Warszawa 2017, s. 876.

${ }^{6} \mathrm{Z}$. Siwıк, Przestępstwa przeciwko rodzinie i opiece, s. 1060. 
nie pozbawia to żadnego z nich władzy rodzicielskiej do czasu ewentualnego sądowego powierzenia tej władzy jednemu $\mathrm{z}$ nich ${ }^{7}$. W jednym z orzeczeń Sąd Najwyższy ${ }^{8}$ stwierdził, że: „Jeżeli sąd w trybie art. $443 \$ 1$ k.p.c. powierza w toku procesu o rozwód tymczasowo małoletnie wspólne dziecko poniżej lat 15 pieczy jednego rodziców, to drugi z rodziców, który uprowadza lub zatrzymuje to dziecko, nie może być podmiotem przestępstwa $\mathrm{z}$ art. 211 k.k., chyba że uprzednio ograniczono już jego władzę rodzicielską albo w trybie art. 443 $\$ 1$ k.p.c. rozstrzygnięto co do sprawowania pieczy przez drugiego z rodziców w sposób podobny do ograniczenia władzy rodzicielskiej, nie zawężając tej decyzji do samego powierzenia pieczy nad dzieckiem i nakazu wydania go danemu rodzicowi, a odebranie dziecka spod pieczy godzi w to ograniczenie lub w ograniczający władzę rodzicielską sposób sprawowania pieczy".

Bardzo ciekawy aspekt tego zagadnienia podnoszą M. Mozgawa, M. Kulik i A. Szczekala. Zauważają bowiem, że jeżeli jedno z rodziców, mając pełnię władzy rodzicielskiej, uprowadza dziecko, czyli zmienia jego miejsce pobytu bez zgody drugiego z rodziców i tym

${ }^{7}$ Postanowienie Sądu Najwyższego z dnia 18 grudnia 1992, sygn. akt I KZP 40/92, Wokanda nr 2/1993, poz. 8: „Oddzielne zamieszkiwanie rodziców i wykonywanie czasowej opieki i nadzoru nad małoletnim dzieckiem przez rodzica, u którego dziecko mieszka w wyniku decyzji sądu wydanej w trybie art. $443 \$ 1$ k.p.c., nie pozbawia, nie ogranicza, jak również nie zawiesza władzy rodzicielskiej drugiego z rodziców. W niczym też nie zmienia zakresu tej władzy w stosunku do dziecka. Powierzenie władzy jednemu z małżonków stron w procesie o rozwód - może nastąpić dopiero w wyroku orzekającym rozwód, przy czym nie jest wykluczone, że władza rodzicielska będzie ewentualnie przyznana temu z małżonków, który w czasie procesu o rozwód w wyniku konieczności tymczasowego uregulowania sposobu wykonywania władzy rodzicielskiej nie sprawował bezpośredniej pieczy nad małoletnim dzieckiem w następstwie postanowienia sądu wydanego na podstawie $443 \$ 1$ k.p.c.”; V. Konarska-Wrzosek, Przestępstwa przeciwko dobrom indywidualnym, w: System prawa karnego, red. J. Warylewski, Warszawa 2010, s. 995; M. SzWARCzy K, Przestępstwa przeciwko rodzinie i opiece, w: Kodeks karny. Komentarz, red. T. Bojarski, Warszawa 2016, s. 611.

${ }^{8}$ Postanowienie Sądu Najwyższego z dnia 9 grudnia 2003, sygn. akt III KK 116/03, LEX nr 83761. 
samym uniemożliwia mu jako uprawnionemu wykonywanie jego prawa do pieczy nad dzieckiem i kierowania nim (narusza jego prawo do opieki), to swoim zachowaniem wypełnia znamiona przestępstwa z art. 211 k.k. Rodzice są zobowiązani do wspólnego decydowania o miejscu pobytu małoletniego, który powinien przebywać w miejscu odpowiadającym woli obojga rodziców mających pełną władzę rodzicielską. Wobec powyższego zdaniem tych Autorów możliwe jest popełnienie czynu zabronionego z art. $211 \mathrm{k} . \mathrm{k}$. w postaci zatrzymania małoletniego przez rodzica mającego pełną władzę rodzicielską. Określenie miejsca pobytu dziecka, czy to stałego, czy to czasowego np. decyzja o wyjeździe dziecka na wakacje za granicę z jednym z rodziców, jest istotną sprawą dotyczącą dziecka i musi być podejmowane wspólnie przez oboje rodziców posiadających władzę rodzicielską w pełnym zakresie ${ }^{9}$.

\section{Znamiona strony przedmiotowej}

Czynność sprawcza omawianego przestępstwa wyraża się w uprowadzeniu lub zatrzymaniu małoletniego poniżej lat 15 albo osoby nieporadnej ze względu na jej stan psychiczny lub fizyczny, wbrew woli osoby powołanej do opieki lub nadzoru. Należy zauważyć, że zarówno uprowadzenie, jak i zatrzymanie charakteryzuje się wyjęciem spod władztwa i przejęciem władzy nad dzieckiem lub osobą nieporadną na krótszy lub dłuższy czas wbrew woli osoby sprawującej opiekę lub nadzór. Osoba uprowadzana lub zatrzymana musi zatem znajdować się pod opieką lub nadzorem. Opieka sprowadza się do czuwania i bieżącego kontrolowania zachowania podopiecznego, jak również wykonywania za niego szeregu czynności, których z racji na wiek lub nieporadność samemu wykonać nie może. Natomiast nadzór przejawia się głównie w kontroli podopiecznego.

Przedmiotem czynności wykonawczej jest osoba małoletnia poniżej lat 15 albo nieporadna ze względu na stan psychiczny lub fizyczny.

\footnotetext{
${ }^{9}$ M. Mozgawa - M. Kulik - A. Szczekala, Przestępstwo uprowadzenia lub zatrzymania małoletniego lub osoby nieporadnej - art. 211 KK (ze szczególnym uwzględnieniem tzw. porwań rodzicielskich), Prawo w Działaniu nr 16/2013, s. 29-30.
} 
Wiek osoby nieporadnej nie ma znaczenia, ponieważ w tym przypadku oceniany jest stan psychiczny i fizyczny. W literaturze można spotkać się z poglądem, że nawet chwilowe zakłócenie samodzielnego zachowania spowodowane np. wysoką gorączką może być podstawą uznania takiej osoby za nieporadną. Jest to jednak stanowisko zbyt daleko idące. Osobą nieporadną jest osoba, która bez pomocy innych, nie jest w stanie poradzić sobie w codziennym życiu. Są to osoby $\mathrm{z}$ niedorozwojem umysłowym, osoby sparaliżowane czy w podeszłym wieku ${ }^{10}$.

Zachowanie sprawcy czynu zabronionego określają alternatywnie dwa znamiona czasownikowe: uprowadza lub zatrzymuje. Uprowadzenie (kidnaping) oznacza porywanie, zabieranie lub zwykłe przemieszczenie podopiecznego $\mathrm{z}$ dotychczasowego miejsca pobytu $\mathrm{w}$ inne. Wiąże się to $\mathrm{z}$ faktycznym pozbawieniem możliwości wykonywania w stosunku do niego dotychczas sprawowanej opieki lub nadzoru przez osoby uprawnione. Nie musi ono być zrealizowane przemocą lub podstępem, ale może być również wynikiem wykorzystania nieobecności albo nieuwagi osoby uprawnionej. Uprowadzenie ma miejsce także wtedy, gdy zabranie osoby pozostającej pod opieką lub nadzorem nastąpiło za jej zgodą. Założeniem ustawodawcy jest bowiem, iż osoba małoletnia lub nieporadna sama o sobie nie może decydowaćl1. Warto także podkreślić, że uprowadzenie nie musi być połączone z rozpoczęciem sprawowania władzy nad podopiecznym np. uprowadzający może go następnie porzucić lub oddać osobie trzeciej niesprawującej nad nim opieki.

Natomiast zatrzymanie odnosi się do sytuacji, w której sprawca skłania lub zmusza podopiecznego do pozostania w miejscu dotychczasowego pobytu wbrew woli osób uprawnionych do sprawowania opieki lub nadzoru, np. samowolne uniemożliwienie małoletniemu przebywającemu czasowo u ojca, powrotu do mieszkania matki sprawującej - zgodnie z wyrokiem sądu - stałą opiekę nad małoletnim. Dlatego znamię zatrzymania jest spełnione również wtedy,

\footnotetext{
${ }^{10}$ R. A. Stefański, Przestępstwo uprowadzenia małoletniego (art. 211 k.k.), s. 60.

${ }^{11}$ S. Hypś, Przestępstwa przeciwko rodzinie i opiece, s. 875-876.
} 
gdy podopieczny znalazł się w miejscu zatrzymania początkowo legalnie, a bezprawnie zostaje tam dłużej bez możliwości swobodnego opuszczenia tego miejsca. Przykładowo dziecko wyjeżdża na kolonie szkolne będąc pod opieką wychowawcy, po zakończeniu obozu wychowawca nie oddaje dziecka rodzicom. Zatrzymanie może, ale nie musi łączyć się z uprzednim uprowadzeniem. O ile uprowadzenie polega wyłącznie na działaniu, o tyle zatrzymanie może polegać zarówno na działaniu, jak również na zaniechaniu' ${ }^{12}$.

W doktrynie przyjmuje się, że uprowadzeniem jest działanie, które prowadzi do tego, że osoba wbrew jej woli zostaje przemieszczona do innego miejsca gdzie obowiązku opieki dokonuje uprowadzający bądź nikt. Przy czym chodzi tutaj jedynie o przemieszczenie faktyczne, nie musi ono wiązać się z przemieszczeniem geograficznym np. do innej miejscowości.

Uprowadzenie lub zatrzymanie podopiecznego jest przestępstwem tylko wtedy, gdy jest popełnione wbrew woli osoby powołanej do opieki lub nadzoru. Dla bytu przestępstwa nie ma znaczenia ewentualna zgoda lub jej brak po stronie podopiecznego. Dla dokonania tego przestępstwa nie jest również konieczne naruszenie praw osoby poddanej opiece. Obojętne dla bytu tego przestępstwa są także pobudki sprawcy. Przy czym są one istotne przy ocenie stopnia społecznej szkodliwości czynu ${ }^{13}$.

Przestępstwo z art. 211 k.k. jest przestępstwem skutkowym. Skutkiem jest pozostające w związku przyczynowym $\mathrm{z}$ uprowadzeniem lub zatrzymaniem rzeczywiste pozbawienie osoby sprawującej nadzór lub opiekę możliwości wypełnienia tego obowiązku. Odmiennie skutek widzi Stefański wskazując, że jest nim uprowadzenie osoby poddanej opiece lub nadzorowi albo jej zatrzymanie, czyli w wypadku uprowadzenia będzie to zmiana miejsca pobytu osoby poddanej nadzorowi, a przy zatrzymaniu - pozostawienie jej w miejscu pobytu ${ }^{14}$.

\footnotetext{
${ }^{12}$ M. Mozgawa, Przestępstwa przeciwko rodzinie i opiece, s. 498.

${ }^{13} \mathrm{~J}$. Kosonoga, Przestepstwa przeciwko rodzinie i opiece, w: Kodeks karny. Komentarz, red. R. Stefański, Warszawa 2017, s. 1332.

${ }^{14}$ R. A. StefańsKi, Przestępstwo uprowadzenia małoletniego (art. 211 k.k.), s. 64-65.
} 


\section{Znamiona strony podmiotowej}

Przedmiotowe przestępstwo charakteryzuje się umyślnością zarówno w formie zamiaru bezpośredniego, jak i ewentualnego. Sprawca musi obejmować zamiarem zarówno fakt, iż dana osoba znajduje się pod opieką lub nadzorem, jak również fakt, że osoba jest osobą małoletnią poniżej 15 lat lub, że jest osobą nieporadną ze względu na stan fizyczny lub psychiczny. Ponadto sprawca musi obejmować zamiarem także znamię zmiany miejsca pobytu osoby znajdującej się pod opieką lub nadzorem oraz to, że działa wbrew woli osoby uprawnionej do opieki i nadzoru ${ }^{15}$. Brak świadomości choćby jednego z wymienionych znamion czynu spowoduje wyłączenie odpowiedzialności karnej sprawcy za uprowadzenie lub zatrzymanie ponieważ kodeks karny nie przewiduje karalności tego typu zachowań o charakterze nieumyślnym. Dlatego przykładowo nie będzie czynem przestępnym jeśli sprawca popełni błąd co do cech osoby będącej przedmiotem czynności wykonawczej bez względu na to czy błąd będzie usprawiedliwiony czy nieusprawiedliwiony.

Podkreślić jeszcze raz należy, że motywy i pobudki, które przyświecają sprawcy przestępstwa nie mają znaczenia dla bytu przestępstwa. Podejmując zamiar uprowadzenia lub zatrzymania, nawet jeśli sprawca działałby ze współczucia czy chęci pomocy nie zmienia kwalifikacji jego czynu. Przestępstwo z art. 211 k.k. zostanie popełnione choćby sprawca uprowadzając małoletniego poniżej lat 15 działał np. z uwagi na chęć pomocy dziecku poprzez zapewnienie mu lepszej edukacji na jaką nie mógłby liczyć będąc pod opieką rodziców czy innych prawnych opiekunów ${ }^{16}$. Należy jednak zgodzić się $\mathrm{z}$ dominującym poglądem doktryny, że motywy i pobudki działania sprawcy powinny być brane pod uwagę przy ocenie stopnia społecznej szkodliwości czynu, zwłaszcza pod kątem realnej ochrony dóbr osoby uprowadzanej lub zatrzymanej.

\footnotetext{
${ }^{15}$ J. Kosonoga, Przestępstwa przeciwko rodzinie i opiece, s. 1332.

${ }^{16}$ S. Hypś, Przestępstwa przeciwko rodzinie i opiece, s. 878.
} 


\section{Sankcja karna}

Przestępstwo z art. 211 k.k. zagrożone jest karą pozbawienia wolności od 3 miesięcy do 5 lat ${ }^{17}$. Co do zasady istnieje możliwość zastosowania instytucji warunkowego umorzenia postępowania karnego, po spełnieniu przesłanek przewidzianych w art. $66 \$ 1$ i 2 k.k. Ustawodawca przewidział, jednak że instytucja ta może mieć zastosowanie jeżeli wina i społeczna szkodliwość czynu nie są znaczne, okoliczności jego popełnienia nie budzą wątpliwości, a postawa sprawcy niekaranego za przestępstwo umyślne, jego właściwości i warunki osobiste oraz dotychczasowy sposób życia uzasadniają przypuszczenie, że pomimo umorzenia postępowania będzie przestrzegał porządku prawnego, w szczególności nie popełni przestępstwa.

Wymierzając karę za przestępstwo uprowadzenia, sąd może zastosować środek karny w postaci zakazu zajmowania określonego stanowiska lub wykonywania określonego zawodu (art. $41 \$ 1$ k.k.).

Jak już wcześniej była mowa, uprowadzenie lub zatrzymanie podopiecznego jest przestępstwem tylko wtedy, gdy jest popełnione wbrew woli osoby powołanej do opieki lub nadzoru. Zgoda lub brak zgody po stronie podopiecznego nie ma znaczenia dla bytu przestępstwa. Niemniej jednak w przypadku braku zgody osoby uprowadzonej wyczerpane zostaną wówczas znamiona przestępstwa $\mathrm{z}$ art. 189 k.k. w takiej sytuacji będziemy mieli do czynienia z kumulatywnym zbiegiem przepisów tj. art. 211 i art. 189 k.k. Możliwy jest także zbieg przepisów art. 211 i $191 \$ 1 \mathrm{k} . \mathrm{k}$. gdy, uprowadzenie lub zatrzymanie połączone było ze stosowaniem przemocy lub groźby bezprawnej wobec osoby uprawnionej do sprawowania opieki lub nadzoru bądź wobec osoby podlegającej opiece lub nadzorowi. Ponadto możliwa jest również kumulatywna kwalifikacja art. 211 k.k. i art. 160 k.k.

\footnotetext{
${ }^{17}$ Sankcja karna uległa podwyższeniu od dnia 13 lipca 2017 r. Do wejścia w życie tej zmiany sprawcy groziła kara pozbawienia wolności do lat 3, dzięki czemu możliwe było zastosowanie instytucji odstąpienia od wymierzenia kary. Przy czym zgodnie $\mathrm{z}$ art. 59 k.k. było to dopuszczalne, jeśli oprócz tego, że przestępstwo zagrożone było karą pozbawienia wolności nieprzekraczającą 3 lat, społeczna szkodliwość czynu nie była znaczna, a sąd orzekł jednocześnie środek karny, przepadek lub środek kompensacyjny i cele kary zostały w ten sposób spełnione.
} 
w zw. z art. $11 \S 2$ k.k. w sytuacji, gdy uprowadzenie lub zatrzymanie naraziło ofiarę na bezpośrednie niebezpieczeństwo utraty życia albo ciężkiego uszczerbku na zdrowiu.

Występek uprowadzenia lub zatrzymania jest przestępstwem publicznoskargowym ściganym z urzędu.

\section{Zakończenie}

Uprowadzenie lub zatrzymanie małoletniego albo osoby nieporadnej ze względu na jej stan psychiczny lub fizyczny wbrew woli osoby powołanej do opieki lub nadzoru jest przestępstwem nawet, jeśli osoba uprowadzona czy zatrzymana zgadza się na to albo wręcz tego sobie życzy. Przeszkodą dla przyjęcia odpowiedzialności karnej za niniejsze przestępstwo może być strona podmiotowa. Otóż, wyrażenie „kto” użyte w art. 211 k.k. wskazuje, iż jest to przestępstwo powszechne. Jednakże w literaturze i orzecznictwie Sądu Najwyższego wskazuje się, iż nie jest możliwe popełnienie tego przestępstwa przez rodzica, którego władza rodzicielska nie została ograniczona. Dlatego też każde z rodziców może być podmiotem tego przestępstwa jedynie w wypadku pozbawienia, ograniczenia lub zawieszenia przysługującej mu władzy rodzicielskiej. Stąd nie stanowi przestępstwa $\mathrm{z}$ art. 211 k.k. zabranie lub zatrzymanie dziecka przez jednego z rodziców wbrew woli drugiego z rodziców, jeżeli oboje wykonują wspólnie władzę rodzicielską, nawet jeśli nie byłoby to zachowanie uzgodnione wspólnie przez rodziców, a nawet jeśli byłoby to zachowanie jednego $\mathrm{z}$ rodziców specjalnie negatywnie nakierowane przeciwko drugiemu.

Przestępstwo z art. 211 k.k. godzi w prawidłowy rozwój rodziny. Ustawodawca podwyższając ustawowe zagrożenie z dotychczasowego (do 3 lat pozbawienia wolności) na karę pozbawienia wolności od 3 miesięcy do lat 5, dał wyraźny znak, że rodzina i sprawowanie opieki są dobrem ważnym i wymagającym ochrony karnej. Założeniem ustawodawcy, podwyższając sankcję karną, było ukazanie, że dotychczasowe zagrożenie za uprowadzenie lub zatrzymanie małoletniego lub osoby nieporadnej było nieadekwatne do stopnia społecznej szkodliwości i nie czyniło zadość obowiązkowi ochrony karnej nad dobrem 
jakim jest rodzina, opieka, ale także w konsekwencji bezpieczeństwo i zdrowie małoletniego czy osoby nieporadnej.

\section{Abduction or detention of a minor or a helpless person in the light of art. 211 of the Criminal Code}

In the article 211 of the Criminal Code in the catalog of offenses against family and care, the legislator stated that anyone who, against the will of a person appointed to care or supervision, abduct or detain a minor under the age of 15 or mentally or physically helpless person shall be subject to the penalty of deprivation of liberty of 3 months up to 5 years. Institution of care and supervision is the legal and statutory protection. At the same time care and supervision are provided for the proper development and well-being of a minor or helpless person. The crime implies the effect of deprivation of legitimate care or supervision over a minor below the age of 15 or a helpless person.

SŁOWA KLUCzOWE: uprowadzenie; rodzina; prawo karne; opieka i nadzór

KEY wORDs: abduction; family; penal law; care and supervision

\section{Nota o Autorze:}

DR KATARZYNA MaJChrzAK - pracownik naukowo-dydaktyczny na Wydziale Prawa Kanonicznego Uniwersytetu Kardynała Stefana Wyszyńskiego w Warszawie, adiunkt w Katedrze Prawa Polskiego, radca prawny. 